\title{
Soluble Klotho and intact fibroblast growth factor 23 in long-term kidney transplant patients
}

\author{
Inger H Bleskestad ${ }^{1}$, Inga Strand Thorsen ${ }^{1}$, Grete Jonsson ${ }^{2}$, Øyvind Skadberg ${ }^{2}$, \\ Harald Bergrem $^{1,3}$ and Lasse G Gøransson ${ }^{1,3}$ \\ ${ }^{1}$ Departments of Internal Medicine and ${ }^{2}$ Medical Biochemistry, Stavanger University Hospital, PO Box 8100, N-4068 \\ Stavanger, Norway and ${ }^{3}$ Department of Clinical Medicine, University of Bergen, Bergen, Norway
}

\begin{abstract}
Background: Controversies exist whether disturbances in mineral and bone disorder (MBD) normalise or persist after kidney transplantation. We assessed markers of MBD in patients with well-functioning kidney transplants to minimise confounding by reduced transplant function.

Methods: In this cross-sectional study, 40 patients aged $\geq 18$ years who received a first kidney transplant more than 10 years ago were included. A well-functioning transplant was defined as an estimated glomerular filtration rate (eGFR) $\geq 45 \mathrm{ml} / \mathrm{min}$ per $1.73 \mathrm{~m}^{2}$.

Results: Median time since transplantation was 18.3 years (inter quartile range (IQR) 12.2-26.2). Albumin-corrected serum calcium levels were above upper limit of normal in 15\% of the transplanted patients, and serum phosphate levels below lower limit of normal in 31\%. The median levels of intact parathyroid hormone (iPTH) and intact fibroblast growth factor 23 (iFGF23) were significantly higher than that in a group of healthy volunteers (11.3 pmol/I (IQR: 8.7-16.2) vs 4.4 pmol/l (IQR: $3.8-5.9), P<0.001$ and $75.0 \mathrm{pg} / \mathrm{ml}$ (IQR: $53.3-108.0)$ vs $51.3 \mathrm{pg} / \mathrm{ml}$ (IQR: $36.3-67.6), P=0.004$ respectively). There was a non-significant reduction in soluble Klotho (sKlotho) levels (605 pg/ml (IQR: 506-784) vs 692 pg/ml (IQR: 618-866)). When compared with a control group matched for eGFR, levels of iPTH were significantly higher $(P<0.001)$, iFGF23 had a non-significant trend towards higher levels and sKlotho towards lower levels.

Conclusions: In long-term kidney transplant patients with well-functioning kidney transplants, we found inappropriately high levels of iPTH and iFGF23 consistent with a state of persistent hyperparathyroidism. We speculate that the primary defect, FGF23 resistance, has evolved in the parathyroid gland before transplantation, and persists due to long half-life of the parathyroid cells.
\end{abstract}

\section{Introduction}

Kidney transplantation is the preferred treatment for patients with end-stage renal disease (ESRD) (1). Many of the biochemical abnormalities of chronic kidney disease-mineral and bone disorder (CKD-MBD) will then be reversed or altered (2).

Parathyroid hormone (PTH) levels decline rapidly during the first 3-6 months after transplantation followed by a more gradual decrease $(3,4)$. In a large proportion of the patients intact PTH (iPTH) levels are elevated even in those with optimal transplant function more than 1 year after transplantation (5). Fibroblast growth factor 23 (FGF23) levels increase with decreasing estimated glomerular filtration rate (eGFR) and is associated with mortality both in dialysis patients, patients with CKD stages $2-4$ and kidney transplant patients $(6,7,8)$. Whether FGF23 levels return to normal during the first year post-transplant (9) or stay elevated for several years is still unclear. $\alpha$-Klotho, characterised as a phosphate and calcium regulatory (c) 2015 European Society of Endocrinology Printed in Great Britain
Published by Bioscientifica Ltd. 
hormone, is an obligate co-receptor for FGF23 in its transmembrane form (10). As a hormone, soluble Klotho (sKlotho) has anti-ageing and cardiovascular protective properties (11) and an assay for measuring sKlotho has recently become commercially available (12). sKlotho has been reported to be associated with eGFR (13), but other studies have reported the levels to be stable for patients in CKD stages 2-4 (14). No data regarding sKlotho levels have to date been reported in long-term kidney transplant patients.

The aim of the present study was to assess the levels of markers of MBD in patients living with a long-term, $>10$ years, well-functioning first kidney transplant defined as an eGFR $\geq 45 \mathrm{ml} / \mathrm{min}$ per $1.73 \mathrm{~m}^{2}$.

\section{Subjects and methods}

The study was designed as a single-centre cross-sectional study. One hundred and ninety one transplanted patients aged $\geq 18$ years attending the nephrology outpatient clinic at Stavanger University Hospital were identified. Of these, 76 patients received a first renal transplant more than 10 years ago and 46 patients had an eGFR $\geq 45 \mathrm{ml} / \mathrm{min}$ per $1.73 \mathrm{~m}^{2}$ and were invited to participate in the study. One patient had undergone a parathyroidectomy and was excluded. One patient declined to participate and another patient was not competent to give consent. Three patients did not attend their scheduled appointment, leaving 40 patients to be included in the study. The study adhered to the 2000 Declaration of Helsinki and was approved by the Regional Medical and Health Research Ethics Committees (REC) Western Norway. Written informed consent was obtained from all participants before inclusion.

\section{Patient characteristics}

Eleven females and 29 males were included, mean age 61.7 years (s.D. 11.7), median time since transplantation 18.3 years (inter quartile range (IQR) 12.2-26.2). Fifteen patients (38\%) were transplanted pre-emptively, median time in dialysis for the remainder (haemodialysis 18 patients (45\%) and peritoneal dialysis seven patients (18\%)) was 0.6 years (range, $0.2-3.0$ years). Twenty-five patients (63\%) received a kidney from a living donor. The underlying causes of CKD were glomerulonephritis ( $n=17,43 \%)$, congenital, including polycystic kidney disease $(n=8,20 \%)$, diabetic nephropathy $(n=4,10 \%)$ and other $(n=11,28 \%)$.

We matched eGFR in the transplanted patients with a source population of CKD patients stage $3 a$ (eGFR $\geq 45 \mathrm{ml} / \mathrm{min}$ per $1.73 \mathrm{~m}^{2}$ ) and higher and healthy volunteers. Each transplanted patient was matched to the person in the source population with the nearest eGFR, giving a control group of 16 females and 23 males, mean age 56.0 years (s.D. 12.4 years). An additional control group consisted of 20 healthy volunteers, mainly health workers at the hospital, 12 females and eight males, mean age 44.2 years (s.D. 14.4 years). Both patients and controls were all Caucasians.

\section{Medications}

In Norway, a standard maintenance immunosuppressive regimen after kidney transplantation includes prednisolone together with a calcineurin inhibitor, an inosine monophosphate dehydrogenase inhibitor or azathioprine depending on the year of transplantation. Twenty-one patients used three different immunosuppressive drugs: ciclosporin or tacrolimus together with either azathioprine or mycophenolate mophetil and prednisolone. Nineteen patients used two immunosuppressive drugs, of which all but one included prednisolone, one patient used an mammalian target of rapamycin (mTOR) inhibitor (everolimus) together with prednisolone and one patient used prednisolone together with a calcinurin inhibitor.

Concomitant medication included one or more anti-hypertensives in 33 patients (83\%) including an angiotensin-converting enzyme inhibitor or angiotensin II receptor blocker in 27 patients (68\%), 31 patients (78\%) a statin as a cholesterol-lowering drug, one patient ezetemibe in monotherapy, three patients active vitamin D (alfacalcidol) $0.25 \mu \mathrm{g}$ daily, one patient calcium carbonate and four patients a bisphosphonate. None of the patients used calcimimetics or any form of nutritional vitamin D medications.

\section{Methods and reference ranges}

eGFR was estimated using the CKD Epidemiology Collaboration (CKD-EPI) equation (15). Serum phosphate (reference range: females, 0.85-1.44; males 13-49 years, $0.78-1.52$ and males $\geq 50$ years, $0.69-1.31 \mathrm{mmol} / \mathrm{l})$, total serum calcium (reference range: $2.15-2.55 \mathrm{mmol} / \mathrm{l}$ ), albumin (reference range: 0-39 years, 36-48 g/l; 40-69 years, 36-45 g/1 and $\geq 70$ years, 34-45 g/l) were analysed using Architect c16000TM (Abbot Diagnostics). Albumincorrected serum calcium (reference range: females $<54$ years, 2.17-2.52 mmol/1; females $\geq 55$ years, $2.20-2.62 \mathrm{mmol} / \mathrm{l}$ and males, $2.17-2.56 \mathrm{mmol} / \mathrm{l})$ was calculated as follows: serum calcium $+0.02 \times(41.3-$ serum albumin $)$. iPTH (reference range: $1.6-8.5 \mathrm{pmol} / \mathrm{l}$ ) was determined using 
an intact PTH assay from Abbot Diagnostics, analysed on an Architect i2000SR (Abbott Diagnostics).

Serum samples were aliquoted and stored at $-72{ }^{\circ} \mathrm{C}$ for later analyses of intact FGF23 (iFGF23), sKlotho and 25(OH)vitamin D. Serum iFGF23 and sKlotho were measured by commercially available ELISA Kits from Kainos Laboratories, Inc. (Tokyo, Japan) and ImmunoBiological Laboratories (IBL, Fujioka, Japan) respectively. Freshly thawed samples were measured in duplicate, and the reproducibility of the methods monitored by analysing three to five aliquots of a serum control with each assay. Intra- and inter-assay coefficient of variation for sKlotho were both $<15 \%$, and for iFGF23 $<7$ and $<11 \%$ respectively. The level of iFGF23, measured with Kainos ELISA Kit, in 104 healthy adults from Japan was reported to be in the range of $8.2-54.3 \mathrm{ng} / \mathrm{l}$ (16) and a reference range of $10-50 \mathrm{ng} / \mathrm{l}$ has been suggested based on these results (17). sKlotho, measured by the IBL ELISA Kit in serum from 142 healthy subjects, was reported to range from 239 to $1266 \mathrm{pg} / \mathrm{ml}$, mean $562 \pm 146 \mathrm{pg} / \mathrm{ml}$ in the original method publication (12). A reference range for males $252-652 \mathrm{pg} / \mathrm{ml}$ and females $177-804 \mathrm{pg} / \mathrm{ml}$ in a healthy Danish population was recently published using the same ELISA Kit (18). Serum 25(OH)vitamin D was quantified by liquid-liquid extraction, derivatisation with 4-phenyl-1,2,4-triazoline-3,5-dione reagent (PTAD, Sigma-Aldrich), and analysis by liquid chromatography coupled with tandem mass spectrometry detection (LC-MS/MS). The level of serum 25(OH)vitamin D was considered deficient $<50 \mathrm{nmol} / 1$, insufficient between 50 and $75 \mathrm{nmol} / \mathrm{l}$ and sufficient $>75 \mathrm{nmol} / \mathrm{l}$ (19).

Urine samples were analysed for concentrations of creatinine (reference range: $4.5-20.0 \mathrm{mmol} / \mathrm{l}$ ), calcium (reference range: $2.0-9.0 \mathrm{mmol} / \mathrm{l}$ ) and phosphate. The fractional excretion of phosphate $\left(\mathrm{FEPO}_{4}\right)$ was calculated as follows: (urine phosphate $\times$ serum creatinine) $\times$ $100 /($ serum phosphate $\times$ urine creatinine). The reference range for $\mathrm{FEPO}_{4}$ in healthy subjects is reported to be 0-20\% (20). sKlotho was analysed in freshly thawed urine aliquots by ELISA as described for serum samples.

\section{Statistical analysis}

Normally distributed data are expressed as mean \pm s.D. and otherwise distributed data are expressed as median and IQR. The results of the study were equivalent when using non-parametric and parametric analyses. We thus chose to use the one-way ANOVA on group comparisons of continuous variables and post hoc analyses were Bonferroni corrected. $\chi^{2}$ test was used for categorical

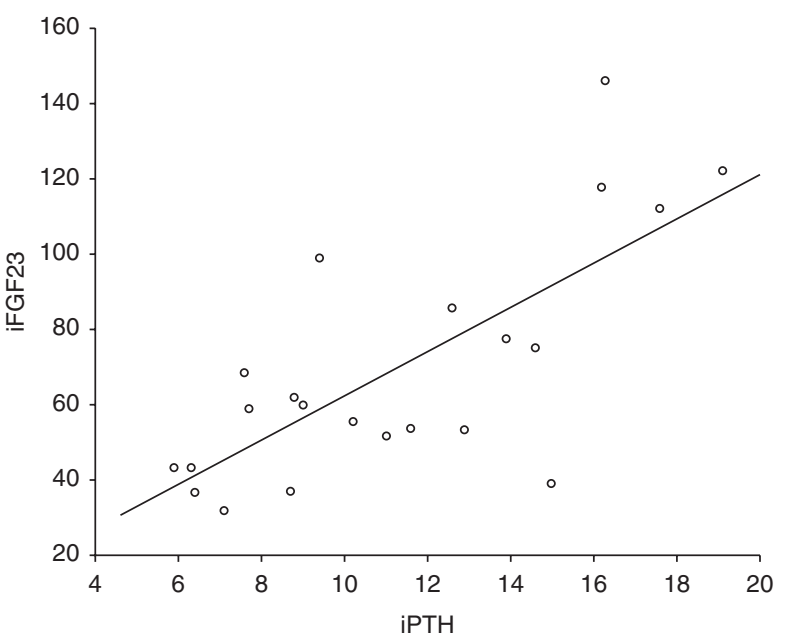

Figure 1

Correlation between iFGF23 in $\mathrm{pg} / \mathrm{ml}$ and $\mathrm{iPTH}$ in $\mathrm{pmol} / \mathrm{l}$ in kidney transplant patients with eGFR $\geq 60 \mathrm{ml} / \mathrm{min}$ per $1.73 \mathrm{~m}^{2}$, eGFR, estimated glomerular filtration rate; iPTH, intact parathyroid hormone; iFGF23, intact fibroblast growth factor 23. The regression line is defined as $Y=3.46+5.86 \times X$, $R^{2}=0.54, P<0.001$.

variables. Correlations were calculated as Spearman's $\rho$. A simple linear regression analysis was used to assess the association between iFGF23 levels as dependent and iPTH levels as independent variable in the group of patients with eGFR $\geq 60 \mathrm{ml} / \mathrm{min}$ per $1.73 \mathrm{~m}^{2}$ (Fig. 1). After correction for multiple testing according to Bonferroni, $P$ values $<0.006$ were considered to be statistically significant. All statistical analyses were conducted using PASW Statistics version 20.0 (SPSS, Inc.).

\section{Results}

The baseline characteristics of all laboratory measurements for 39 of the transplanted patients, the 39 eGFRmatched controls and the group of healthy volunteers $(n=20)$ are given in Table 1 . One transplanted patient was excluded from the main analyses as a result of an extreme vitamin D deficiency, and is reported separately at the end of this section, illustrating the impact of vitamin D on markers of MBD (Table 2).

Post hoc analysis showed that there was no statistically significant difference in age between the kidney transplant patients and the eGFR-matched controls $(61.3 \pm 11.8$ years vs $56.0 \pm 12.4$ years, $P=0.20$ ). The healthy volunteers were significantly younger than the eGFR-matched controls $(44.2 \pm 14.4$ years vs $56.0 \pm 12.4$ years, $P=0.003)$. 
Table 1 Baseline characteristics of the transplanted patients, the 39 eGFR-matched controls and the group of healthy volunteers. Data are presented as median (IQR), and mean \pm s.D. unless otherwise stated, and groups are compared using ${ }^{a} \chi^{2}$-test and one-way ANOVA.

\begin{tabular}{|c|c|c|c|c|}
\hline & $\begin{array}{l}\text { Kidney transplant patients } \\
\qquad(n=39)\end{array}$ & $\begin{array}{l}\text { eGFR-matched controls } \\
\qquad(n=39)\end{array}$ & $\begin{array}{l}\text { Healthy volunteers } \\
\qquad(n=20)\end{array}$ & $P$ values \\
\hline Sex & 10 females, 29 males & 16 females, 23 males & 12 females, 8 males & $0.04^{a}$ \\
\hline Age (years) & $61.3 \pm 11.8$ & $56.0 \pm 12.4$ & $44.2 \pm 14.4$ & $<0.001$ \\
\hline Serum calcium $(\mathrm{mmol} / \mathrm{l})$ & $2.42 \pm 0.15$ & $2.41 \pm 0.09$ & $2.43 \pm 0.07$ & 0.20 \\
\hline Alb cor calcium (mmol/l) & $2.41 \pm 0.13$ & $2.42 \pm 0.08$ & $2.40 \pm 0.07$ & 0.46 \\
\hline Serum phosphate $(\mathrm{mmol} / \mathrm{l})$ & $0.92 \pm 0.22$ & $1.10 \pm 0.17$ & $1.12 \pm 0.19$ & $<0.001$ \\
\hline $25(\mathrm{OH})$ vitamin D (nmol/l) & $51.9 \pm 18.4$ & $64.1 \pm 16.2$ & $76.2 \pm 16.5$ & $<0.001$ \\
\hline Creatinine $(\mu \mathrm{mol} / \mathrm{l})$ & $101.0(89.0-123.0)$ & $104.0(91.0-114.0)$ & $70.0(61.0-77.3)$ & $<0.001$ \\
\hline eGFR $\left(\mathrm{ml} / \mathrm{min}\right.$ per $\left.1.73 \mathrm{~m}^{2}\right)$ & $62.0(52.0-72.0)$ & $62.0(57.0-73.0)$ & $99.5(89.5-110.8)$ & $<0.001$ \\
\hline iPTH (pmol/l) & $11.3(8.7-16.2)$ & $7.6(5.5-10.5)$ & $4.4(3.8-5.9)$ & $<0.001$ \\
\hline iFGF23 (pg/ml) & $75.0(53.3-108.0)$ & $62.7(51.8-86.6)$ & $51.3(36.3-67.6)$ & 0.005 \\
\hline Klotho (pg/ml) & 605 (506-784) & $660(536-847)$ & $692(618-866)$ & 0.46 \\
\hline $\mathrm{FEPO}_{4}(\%)$ & $32.6(23.1-41.2)$ & $25.5(19.9-29.6)$ & $9.3(6.9-15.6)$ & $<0.001$ \\
\hline Urine calcium (mmol/l) & $0.8(<0.5-1.4)$ & $1.6(0.9-2.3)$ & $2.5(1.4-4.7)$ & $<0.001$ \\
\hline Urine Klotho (pg/ml) & $303.0(86.2-767.0)$ & ND & ND & \\
\hline
\end{tabular}

Alb cor, albumin corrected; eGFR, estimated glomerular filtration rate; iPTH, intact parathyroid hormone; iFGF23, intact fibroblast growth factor 23; $\mathrm{FEPO}_{4}$, fractional excretion of phosphate; ND, not done.

Statistically significant differences in serum phosphate, iPTH levels and $\mathrm{FEPO}_{4}$ were found when comparing the kidney transplant patients with the eGFR-matched controls $(0.92 \pm 0.22 \mathrm{mmol} / \mathrm{l}$ vs $1.10 \pm 0.17 \mathrm{mmol} / \mathrm{l}$, $P=0.002,11.3 \mathrm{pmol} / \mathrm{l}(8.7-16.2)$ vs $7.6 \mathrm{pmol} / \mathrm{l}(5.5-10.5)$, $P<0.001$, and $32.6 \%(23.1-41.2)$ vs $25.5 \%$ (19.9-29.6), $P<0.001$ respectively). 25( $\mathrm{OH})$ vitamin D levels were non-significantly higher in the eGFR-matched controls

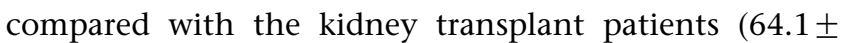
$16.2 \mathrm{nmol} / 1$ vs $51.9 \pm 18.4 \mathrm{nmol} / \mathrm{l}, P=0.007)$. iFGF23 levels were significantly lower in healthy volunteers compared with kidney transplant patients (51.3 (36.367.6) $\mathrm{pg} / \mathrm{ml}$ vs $75.0(53.3-108.0) \mathrm{pg} / \mathrm{ml}, P=0.004)$.
Albumin-corrected calcium levels were above upper limit of normal (ULN) in six patients (15\%), none below lower limit of normal (LLN). Thirteen patients had urine calcium levels below the detection limit for the method used and another ten patients had levels below LLN, giving a total of 33 patients (85\%) with urine calcium levels below LLN. The serum phosphate level was above ULN $(1.32 \mathrm{mmol} / \mathrm{l})$ in one patient, while 12 patients (31\%) had levels below LLN. FEPO 4 was above ULN in 33 patients $(85 \%)$. 25(OH)vitamin D levels were deficient $(<50 \mathrm{nmol} / \mathrm{l})$ in 16 patients $(41 \%)$, insufficient $(50-75 \mathrm{nmol} / \mathrm{l})$ in 17 patients $(44 \%)$ and sufficient (>75 nmol/l) in six patients (15\%). Thirty patients (77\%)

Table 2 Laboratory data of patient with extreme vitamin D deficiency. At time of transplantation her iPTH was $52 \mathrm{pmol} / \mathrm{l}$, 10 weeks after transplantation $13 \mathrm{pmol} / \mathrm{l}$.

\begin{tabular}{l}
\hline \\
\hline Calcium (mmol/l) \\
Albumin-corrected calcium $(\mathrm{mmol} / \mathrm{l})$ \\
Phosphate $(\mathrm{mmol} / \mathrm{l})$ \\
Creatinine $(\mu \mathrm{mol} / \mathrm{l})$ \\
eGFR $\left(\mathrm{ml} / \mathrm{min} \mathrm{per} 1.73 \mathrm{~m}^{2}\right)$ \\
$25(\mathrm{OH}) \mathrm{vitamin} \mathrm{D}(\mathrm{nmol} / \mathrm{l})$ \\
iPTH $(\mathrm{pmol} / \mathrm{l})$ \\
iFGF23 $(\mathrm{pg} / \mathrm{ml})$ \\
Klotho $(\mathrm{pg} / \mathrm{ml})$ \\
Urine calcium $(\mathrm{mmol} / \mathrm{l})$ \\
FEPO $_{4}(\%)$ \\
\hline
\end{tabular}

\begin{tabular}{c}
\hline $\begin{array}{c}\text { At inclusion } \\
\mathbf{1 0 . 5} \text { years after } \\
\text { transplantation }\end{array}$ \\
\hline 2.06 \\
2.12 \\
0.8 \\
60 \\
85 \\
1.6 \\
68.4 \\
8.7 \\
1197 \\
0.6 \\
17.9 \\
\hline
\end{tabular}

\begin{tabular}{c}
\hline $\begin{array}{c}\text { After } 2 \text { weeks of } \\
\text { high-dose vitamin D } \\
\text { treatment }\end{array}$ \\
\hline 2.15 \\
2.23 \\
1.2 \\
57 \\
87 \\
48.5 \\
32.8 \\
12.4 \\
1228 \\
$<0.5$ \\
18.9
\end{tabular}

\begin{tabular}{c}
\hline $\begin{array}{c}\text { After } 8 \text { weeks of } \\
\text { high-dose vitamin } D \\
\text { treatment }\end{array}$ \\
\hline 2.00 \\
2.23 \\
1.3 \\
92 \\
52 \\
120.0 \\
15.0 \\
87.9 \\
455 \\
ND \\
ND
\end{tabular}

\begin{tabular}{c}
\hline $\begin{array}{c}\text { Five months after } \\
\text { cessation of high-dose } \\
\text { vitamin D treatment }\end{array}$ \\
\hline 2.38 \\
2.43 \\
1.2 \\
72 \\
70 \\
75.3 \\
8.0 \\
54.3 \\
994 \\
0.7 \\
ND
\end{tabular}

Vitamin D, cholecalciferol; eGFR, estimated glomerular filtration rate; iPTH, intact parathyroidhormone; iFGF23, intact fibroblast growth factor 23; $\mathrm{FEPO}_{4}$, fractional excretion of phosphate; ND, not done. 
had an iPTH level above ULN, none below LLN. Thirty-one patients (79\%) had iFGF23 levels above $50 \mathrm{pg} / \mathrm{ml}$. Nine patients had undetectable levels of sKlotho in the urine (u-Klotho) and one patient had a very high level: $4816 \mathrm{pg} / \mathrm{ml}$.

\section{Correlations}

There was a strong linear correlation between PTH and FGF23 levels (Spearman's $r=0.50, P=0.001$ ) in the kidney transplant patients. In the subgroup of patients with eGFR $\geq 60 \mathrm{ml} / \mathrm{min}$ per $1.73 \mathrm{~m}^{2}$, the correlation was even stronger (Spearman's $r=0.68, P=0.001$ ) (Fig. 1).

\section{Case report}

One patient had secondary hyperparathyroidism (SHPT) due to a pronounced vitamin D deficiency $(25(\mathrm{OH})$ vitamin D $1.6 \mathrm{nmol} / \mathrm{l}$ ) (Table 2). She was excluded from the main analysis of the study and was given cholecalciferol 70000 IU/week for 8 weeks. We followed the study protocol when blood was drawn for control of therapy, and this enabled us to report the effects of cholecalciferol treatment on all markers of mineral metabolism, including sKlotho (Table 2). The underlying cause of her CKD was a focal segmental glomerulonephritis. She received a pre-emptive kidney transplant from a deceased donor 10.5 years before inclusion. Five years after transplantation, she fell and sustained a Colles fracture. A dual-energy $\mathrm{X}$-ray absorptiometry scan showed a $T$-score of -4.33 s.D. in L1-L4 and -3.54 s.D. in the left femoral neck. Treatment with alendronate $70 \mathrm{mg}$ once every week was started. There were no indications of other underlying diseases such as malabsorption. Her diet was very strictly vegetarian, and she mostly avoided direct sunlight due to fear of skin cancer, both contributing to her vitamin D deficiency. Two days before the high-dose substitution regimen with vitamin $\mathrm{D}$ was scheduled to end, she stumbled and fell and fractured her right femoral neck. She was admitted to hospital and operated the following day. The eGFR fell temporarily. A follow up laboratory assessment was done 5 months after the cholecalciferol treatment in high dosing had ended.

\section{Discussion}

Persistent hyperparathyroidism in kidney transplant recipients is characterised by elevated PTH levels together with specific post-transplant complications such as hypercalcaemia, hypophosphataemia and nephrocalcinosis (2).
In long-term kidney transplant patients, we found elevated iPTH together with serum calcium levels within or above ULN, and elevated iFGF23 together with serum phosphate levels within or below LLN. These findings are consistent with a state of persistent hyperparathyroidism. Our patients had eGFR $\geq 45 \mathrm{ml} / \mathrm{min}$ per $1.73 \mathrm{~m}^{2}$ contributing to a normal response to PTH and FGF23 in the kidney transplant, resulting in very low urine calcium levels and higher excretion of phosphate than the serum levels would imply.

Known risk factors for developing persistent hyperparathyroidism after transplantation are longer time in dialysis and severe SHPT at the time of transplantation (21). About one-third (37.5\%) of our patients were preemptively transplanted, and time on dialysis for the remainder was relatively short. Unfortunately, we do not have information of PTH levels before transplantation. SHPT develops early in patients with CKD, affects most patients during the course of their disease (22), and a diffuse or nodular parathyroid hyperplasia ensue (23). Our findings of persisting markers of MBD more than 10 years after successful transplantation may be explained by the longevity of parathyroid cells, their mean life span being 20 years (24).

The levels of 25(OH)vitamin D were below $50 \mathrm{nmol} / \mathrm{l}$ in $41 \%$ of our patients, and significantly lower when compared with the group of healthy volunteers. $25(\mathrm{OH})$ vitamin D is affecting the levels of PTH and thus might have influenced our result. However, vitamin D deficiency increases the level of PTH and decreases the level of FGF23 as previously reported (25) and illustrated in our case report. A concomitant increase in PTH and FGF23 may reflect a disturbance in the bone-parathyroid feedback axis probably due to a downregulation of the Klotho/FGF receptor complex in hyperplastic parathyroid glands (26). Our 'case patient's' iFGF23 level was initially very low, most likely due to low vitamin D levels and low phosphate content of her vegetarian diet, and her iPTH level was high. When she was treated with high doses of cholecalciferol, iPTH levels fell and iFGF23 levels rose markedly as 25(OH)vitamin D levels increased, reflecting disturbances in MBD as a result of vitamin D deficiency. sKlotho remained stable during the initial phase of cholecalciferol treatment. At the time of cessation of vitamin D therapy she was admitted to hospital, and had a transient fall in eGFR, and we hypothesise that this was the main reason for the concomitant transient reduction in sKlotho (Table 2) (27).

The human Klotho gene has two transcripts resulting in two forms of sKlotho, the shed-product of the 
trans-membrane form and the secreted form (28). The commercially available assay (12) measures the shedproduct of the trans-membrane form (29), and in addition there are indications that only this form exists in extracellular fluids in humans (30). Our 'case patient's' transient fall in eGFR together with a transient reduction in sKlotho levels give support to the notion that sKlotho is associated with acute kidney failure. This might be explained by a down-regulation of the cleavage enzymes secretases (31) in an acute kidney failure, rendering Klotho function at the tissue level intact. In a state of chronic kidney failure, a new steady-state between sKlotho and membrane-bound Klotho may develop over time. We believe that the nonsignificant reduction in sKlotho levels in the transplanted patients was most likely due to well-functioning kidney transplants. Others have found a weak association between sKlotho and age $(12,14)$. However, there was no such association in our subjects, and our finding thus needs to be confirmed in larger studies.

Our transplanted patients had significantly higher iFGF23 levels than the healthy volunteers, and a nonsignificant trend towards higher levels when compared with the eGFR-matched controls, which is in contrast to the results of Sirilak et al. (32). They found that in longterm kidney transplant patients in Thailand, C-terminal FGF23 (cFGF23) was elevated only in the patients with stage T3 (CKD stage after transplantation) and T4 compared with a control group of healthy individuals. The patients in stages T1 and T2 had significantly lower levels of cFGF23. The reported levels in that study are markedly lower compared with other studies using the same cFGF23 assay. Forty-six normal subjects in Sirilak et al.'s (32) study had a median cFGF23 level of $18 \mathrm{RU} / \mathrm{ml}$ (IQR: 14-24 RU/ml). Ninety-five percent reference limits has recently been reported to be $21.6-91.0 \mathrm{RU} / \mathrm{ml}$ (33). The difference might be due to methodological problems, issues of calibration and possibly racial differences, which need to be further explored. Another study of 279 long-term kidney transplant patients concluded that FGF23 concentrations remained increased a median of 7.1 years after transplantation even in patients with eGFR $>60 \mathrm{ml} / \mathrm{min}$ per $1.73 \mathrm{~m}^{2}$ (34). It is however difficult to interpret their FGF23 results due to inconsistencies as to which assay for measuring FGF23 was used, and the study did not include a control group.

\section{Strengths and limitations}

None of the current ELISA methods for measuring FGF23 and sKlotho have been subject to international standardisation and show poor agreement $(35,36)$. It is not possible to compare results between different laboratories and the diversity in reported results is large. Inclusion of a control group is necessary for any conclusions to be drawn from a study before standardised reference limits are established. The control group of healthy volunteers were younger when compared with the transplanted group of patients. The eGFR-matched control group was, however, not statistically younger when compared with the kidney transplant patients. Both patients and controls were all Caucasians, and our results can thus not be extended to populations of other ethnicities. We included kidney transplant patients with substantially longer time since transplantation in contrast to earlier studies, which included patients from 2.5 to 3.5 years post-transplant $(32,34)$.

We included patients with a well-functioning kidney transplant in order to reduce confounding by graft function. A cut-off value of $45 \mathrm{ml} / \mathrm{min}$ per $1.73 \mathrm{~m}^{2}$ was chosen as there is no association between eGFR and cardiovascular morbidity and mortality in kidney transplant patients above this level (37). This value also corresponds to the division of CKD stage 3 in stages $3 \mathrm{a}$ and $3 \mathrm{~b}$. Cross-sectional studies indicate that changes in PTH are evident when eGFR falls below $45 \mathrm{ml} / \mathrm{min}$ per $1.73 \mathrm{~m}^{2}$, whereas changes in FGF23 and Klotho may occur earlier. In a recently published study, FGF23 levels have increased with an eGFR of $<47 \mathrm{ml} / \mathrm{min}$ per $1.73 \mathrm{~m}^{2}$ (CI: $39-56 \mathrm{ml} / \mathrm{min}$ per $1.73 \mathrm{~m}^{2}$ ) (38). Median eGFR in our patients was $62.0 \mathrm{ml} / \mathrm{min}$ per $1.73 \mathrm{~m}^{2}$ (IQR: $52.0-72.0 \mathrm{ml} / \mathrm{min}$ per $1.73 \mathrm{~m}^{2}$ ). By including a control group of patients matched for eGFR, we found a trend towards higher iFGF23 levels and lower sKlotho levels in the kidney transplant patients not attributable to reduced graft function. These results were however not statistically significant, most likely due to lack of statistical power.

Use of active vitamin D increases iFGF23 levels and lowers iPTH levels (39) and this might have influenced the relationship between PTH and FGF23 in our study. Three patients used active vitamin $\mathrm{D}$, all of which had eGFR values between 45 and $60 \mathrm{ml} / \mathrm{min}$ per $1.73 \mathrm{~m}^{2}$. The correlation between PTH and FGF23 in the patients with eGFR $\geq 60 \mathrm{ml} / \mathrm{min}$ per $1.73 \mathrm{~m}^{2}$ (Fig. 1), was thus not influenced by the use of active vitamin $\mathrm{D}$ and is consistent with a state of FGF23 resistance of the parathyroid gland. The cross-sectional design of our study has its limitations, and our hypotheses must be further explored in additional studies. 


\section{Conclusions}

In long-term kidney transplant patients ( $>10$ years posttransplant) with a well-functioning kidney transplant ( $\geq 45 \mathrm{ml} / \mathrm{min}$ per $1.73 \mathrm{~m}^{2}$ ), we found a high prevalence of disturbances in markers of MBD with inappropriately high levels of iFGF23. We speculate that the primary defect has evolved in the parathyroid gland before transplantation, and persists due to long half-life of the parathyroid cells. In this context, pre-transplant effective treatment of MBD is of outmost importance.

\section{Declaration of interest}

The authors declare that there is no conflict of interest that could be perceived as prejudicing the impartiality of the research reported.

\section{Funding}

The study was supported by an educational grant from Stavanger University Hospital.

\section{Author contribution statement}

L G Gøransson and I H Bleskestad designed study; I H Bleskestad, I S Thorsen, G Jonsson and L G Gøransson performed patient management and data collection; I H Bleskestad, I S Thorsen, G Jonsson, Ø Skadberg and L G Gøransson carried out data analyses; I H Bleskestad, H Bergrem and L G Gøransson wrote the manuscript. All authors read and approved the final manuscript.

\section{Acknowledgements}

The authors would like to thank Cato Brede, Department of Medical Biochemistry, Stavanger University Hospital (Stavanger, Norway) for carrying out the vitamin D analyses.

\section{References}

1 Wolfe RA, Ashby VB, Milford EL, Ojo AO, Ettenger RE, Agodoa LY, Held PJ \& Port FK. Comparison of mortality in all patients on dialysis, patients on dialysis awaiting transplantation, and recipients of a first cadaveric transplant. New England Journal of Medicine 1999341 1725-1730. (doi:10.1056/NEJM199912023412303)

2 Evenepoel P. Recovery versus persistence of disordered mineral metabolism in kidney transplant recipients. Seminars in Nephrology 2013 33 191-203. (doi:10.1016/j.semnephrol.2012.12.019)

3 Bonarek H, Merville P, Bonarek M, Moreau K, Morel D, Aparicio M \& Potaux L. Reduced parathyroid functional mass after successful kidney transplantation. Kidney International 199956 642-649. (doi:10.1046/j. 1523-1755.1999.00589.x)

4 Evenepoel P, Claes K, Kuypers D, Maes B, Bammens B \& Vanrenterghem Y. Natural history of parathyroid function and calcium metabolism after kidney transplantation: a single-centre study. Nephrology, Dialysis, Transplantation 200419 1281-1287. (doi:10.1093/ ndt/gfh128)
5 Bleskestad IH, Bergrem H, Leivestad T \& Goransson LG. Intact parathyroid hormone levels in renal transplant patients with normal transplant function. Clinical Transplantation 201125 E566-E570. (doi:10.1111/j.1399-0012.2011.01515.x)

6 Gutierrez OM, Mannstadt M, Isakova T, Rauh-Hain JA, Tamez H, Shah A, Smith K, Lee H, Thadhani R, Juppner H et al. Fibroblast growth factor 23 and mortality among patients undergoing hemodialysis. New England Journal of Medicine 2008359 584-592. (doi:10.1056/ NEJMoa0706130)

7 Isakova T, Wahl P, Vargas GS, Gutierrez OM, Scialla J, Xie H, Appleby D, Nessel L, Bellovich K, Chen J et al. Fibroblast growth factor 23 is elevated before parathyroid hormone and phosphate in chronic kidney disease. Kidney International 201179 1370-1378. (doi:10.1038/ki.2011.47)

8 Wolf M, Molnar MZ, Amaral AP, Czira ME, Rudas A, Ujszaszi A, Kiss I, Rosivall L, Kosa J, Lakatos P et al. Elevated fibroblast growth factor 23 is a risk factor for kidney transplant loss and mortality. Journal of the American Society of Nephrology 201122 956-966. (doi:10.1681/ASN. 2010080894)

9 Evenepoel P, Meijers BK, de Jonge H, Naesens M, Bammens B, Claes K, Kuypers D \& Vanrenterghem Y. Recovery of hyperphosphatoninism and renal phosphorus wasting one year after successful renal transplantation. Clinical Journal of the American Society of Nephrology 20083 1829-1836. (doi:10.2215/CJN.01310308)

$10 \mathrm{Hu}$ MC, Kuro-o M \& Moe OW. Renal and extrarenal actions of Klotho. Seminars in Nephrology 201333 118-129. (doi:10.1016/j.semnephrol. 2012.12.013)

11 Drueke TB \& Massy ZA. Circulating Klotho levels: clinical relevance and relationship with tissue Klotho expression. Kidney International $2013 \mathbf{8 3}$ 13-15. (doi:10.1038/ki.2012.370)

12 Yamazaki Y, Imura A, Urakawa I, Shimada T, Murakami J, Aono Y, Hasegawa H, Yamashita T, Nakatani K, Saito Y et al. Establishment of sandwich ELISA for soluble $\alpha$-Klotho measurement: age-dependent change of soluble $\alpha$-Klotho levels in healthy subjects. Biochemical and Biophysical Research Communications 2010398 513-518. (doi:10.1016/ j.bbrc.2010.06.110)

13 Kim HR, Nam BY, Kim DW, Kang MW, Han JH, Lee MJ, Shin DH, Doh FM, Koo HM, Ko KI et al. Circulating $\alpha$-Klotho levels in CKD and relationship to progression. American Journal of Kidney Diseases 201361 899-909. (doi:10.1053/j.ajkd.2013.01.024)

14 Seiler S, Wen M, Roth HJ, Fehrenz M, Flugge F, Herath E, Weihrauch A, Fliser D \& Heine GH. Plasma Klotho is not related to kidney function and does not predict adverse outcome in patients with chronic kidney disease. Kidney International 201383 121-128. (doi:10.1038/ ki.2012.288)

15 Levey AS, Stevens LA, Schmid CH, Zhang YL, Castro AF III, Feldman HI, Kusek JW, Eggers P, Van Lente F, Greene T et al. A new equation to estimate glomerular filtration rate. Annals of Internal Medicine 2009150 604-612. (doi:10.7326/0003-4819-150-9-200905050-00006)

16 Yamazaki Y, Okazaki R, Shibata M, Hasegawa Y, Satoh K, Tajima T, Takeuchi Y, Fujita T, Nakahara K, Yamashita T et al. Increased circulatory level of biologically active full-length FGF-23 in patients with hypophosphatemic rickets/osteomalacia. Journal of Clinical Endocrinology and Metabolism 200287 4957-4960. (doi:10.1210/ jc.2002-021105)

17 Yamashita H, Yamashita T, Miyamoto M, Shigematsu T, Kazama JJ, Shimada T, Yamazaki Y, Fukumoto S, Fukagaw M \& Noguchi S. Fibroblast growth factor (FGF)-23 in patients with primary hyperparathyroidism. European Journal of Endocrinology 2004151 55-60. (doi:10.1530/eje.0.1510055)

18 Pedersen L, Pedersen SM, Brasen CL \& Rasmussen LM. Soluble serum Klotho levels in healthy subjects. Comparison of two different immunoassays. Clinical Biochemistry 201346 1079-1083. (doi:10.1016/ j.clinbiochem.2013.05.046)

19 Holick MF, Binkley NC, Bischoff-Ferrari HA, Gordon CM, Hanley DA, Heaney RP, Murad MH, Weaver CM \& Endocrine Society. Evaluation, treatment, and prevention of vitamin D deficiency: an Endocrine 
Society clinical practice guideline. Journal of Clinical Endocrinology and Metabolism 201196 1911-1930. (doi:10.1210/jc.2011-0385)

20 Burnett SM, Gunawardene SC, Bringhurst FR, Juppner H, Lee H \& Finkelstein JS. Regulation of C-terminal and intact FGF-23 by dietary phosphate in men and women. Journal of Bone and Mineral Research 200621 1187-1196. (doi:10.1359/jbmr.060507)

21 Evenepoel P, Sprangers B, Lerut E, Bammens B, Claes K, Kuypers D, Meijers B \& Vanrenterghem Y. Mineral metabolism in renal transplant recipients discontinuing cinacalcet at the time of transplantation: a prospective observational study. Clinical Transplantation 201226 393-402. (doi:10.1111/j.1399-0012.2011.01524.x)

22 Levin A, Bakris GL, Molitch M, Smulders M, Tian J, Williams LA \& Andress DL. Prevalence of abnormal serum vitamin D, PTH, calcium, and phosphorus in patients with chronic kidney disease: results of the study to evaluate early kidney disease. Kidney International $2007 \mathbf{7 1}$ 31-38. (doi:10.1038/sj.ki.5002009)

23 Tominaga Y, Tanaka Y, Sato K, Nagasaka T \& Takagi H. Histopathology, pathophysiology, and indications for surgical treatment of renal hyperparathyroidism. Seminars in Surgical Oncology 199713 78-86. (doi:10. 1002/(SICI) 1098-2388(199703/04)13:2 < 78::AID-SSU3 > 3.0.CO;2-Z)

24 Parfitt AM. The hyperparathyroidism of chronic renal failure: a disorder of growth. Kidney International 199752 3-9. (doi:10.1038/ki.1997.297)

25 Marckmann P, Agerskov H, Thineshkumar S, Bladbjerg EM, Sidelmann JJ, Jespersen J, Nybo M, Rasmussen LM, Hansen D \& Scholze A. Randomized controlled trial of cholecalciferol supplementation in chronic kidney disease patients with hypovitaminosis D. Nephrology, Dialysis, Transplantation 201227 3523-3531. (doi:10.1093/ ndt/gfs138)

26 Komaba H, Goto S, Fujii H, Hamada Y, Kobayashi A, Shibuya K, Tominaga Y, Otsuki N, Nibu K, Nakagawa K et al. Depressed expression of Klotho and FGF receptor 1 in hyperplastic parathyroid glands from uremic patients. Kidney International 201077 232-238. (doi:10.1038/ ki.2009.414)

27 Hu MC, Shi M, Zhang J, Quinones H, Kuro-o M \& Moe OW. Klotho deficiency is an early biomarker of renal ischemia-reperfusion injury and its replacement is protective. Kidney International $2010 \mathbf{7 8}$ 1240-1251. (doi:10.1038/ki.2010.328)

28 Matsumura Y, Aizawa H, Shiraki-Iida T, Nagai R, Kuro-o M \& Nabeshima Y. Identification of the human Klotho gene and its two transcripts encoding membrane and secreted Klotho protein. Biochemical and Biophysical Research Communications 1998242 626-630. (doi:10.1006/bbrc.1997.8019)

29 Donate-Correa J, Muros de Fuentes M, Mora-Fernandez C \& Navarro-Gonzalez JF. Pathophysiological implications of fibroblast growth factor-23 and Klotho and their potential role as clinical biomarkers. Clinical Chemistry 201460 933-940. (doi:10.1373/ clinchem.2013.206649)

30 Imura A, Iwano A, Tohyama O, Tsuji Y, Nozaki K, Hashimoto N, Fujimori T \& Nabeshima Y. Secreted Klotho protein in sera and CSF: implication for post-translational cleavage in release of Klotho protein from cell membrane. FEBS Letters 2004565 143-147. (doi:10.1016/ j.febslet.2004.03.090)

31 Bloch L, Sineshchekova O, Reichenbach D, Reiss K, Saftig P, Kuro-o M \& Kaether C. Klotho is a substrate for $\alpha$-, $\beta$ - and $\gamma$-secretase. FEBS Letters 2009583 3221-3224. (doi:10.1016/j.febslet.2009.09.009)

32 Sirilak S, Chatsrisak K, Ingsathit A, Kantachuvesiri S, Sumethkul V, Stitchantrakul W, Radinahamed P \& Disthabanchong S. Renal phosphate loss in long-term kidney transplantation. Clinical Journal of the American Society of Nephrology 20127 323-331. (doi:10.2215/CJN. 06380611)

33 Smith ER, Cai MM, McMahon LP \& Holt SG. Biological variability of plasma intact and C-terminal FGF23 measurements. Journal of Clinical Endocrinology and Metabolism 201297 3357-3365. (doi:10.1210/jc. 2012-1811)

34 Sanchez Fructuoso AI, Maestro ML, Perez-Flores I, Valero R, Rafael S, Veganzones S, Calvo N, De la Orden V, De la Flor JC, Valga F et al. Serum level of fibroblast growth factor 23 in maintenance renal transplant patients. Nephrology, Dialysis, Transplantation 201227 4227-4235. (doi:10.1093/ndt/gfs409)

35 Smith ER, McMahon LP \& Holt SG. Fibroblast growth factor 23. Annals of Clinical Biochemistry 201451 203-227. (doi:10.1177/ 0004563213510708)

36 Heijboer AC, Blankenstein MA, Hoenderop J, de Borst MH, Vervloet MG \& NIGRAM Consortium. Laboratory aspects of circulating a-Klotho. Nephrology, Dialysis, Transplantation 201328 2283-2287. (doi:10.1093/ndt/gft236)

37 Weiner DE, Carpenter MA, Levey AS, Ivanova A, Cole EH, Hunsicker L, Kasiske BL, Kim SJ, Kusek JW \& Bostom AG. Kidney function and risk of cardiovascular disease and mortality in kidney transplant recipients: the FAVORIT trial. American Journal of Transplantation $2012 \mathbf{1 2}$ 2437-2445. (doi:10.1111/j.1600-6143.2012.04101.x)

38 Pavik I, Jaeger P, Ebner L, Wagner CA, Petzold K, Spichtig D, Poster D, Wuthrich RP, Russmann S \& Serra AL. Secreted Klotho and FGF23 in chronic kidney disease stage 1 to 5 : a sequence suggested from a crosssectional study. Nephrology, Dialysis, Transplantation 201328 352-359. (doi:10.1093/ndt/gfs460)

39 Bleskestad IH, Bergrem H, Hartmann A, Godang K \& Goransson LG. Fibroblast growth factor 23 and parathyroid hormone after treatment with active vitamin $\mathrm{D}$ and sevelamer carbonate in patients with chronic kidney disease stage 3b, a randomized crossover trial. BMC Nephrology 201213 49. (doi:10.1186/1471-2369-13-49)

Received 6 June 2014

Revised version received 4 December 2014

Accepted 7 January 2015 